\title{
LICHENS FROM THE ZEMPLÍNSKE VRCHY MTS AND PHYSCIA LEPTALEA NEW TO SLOVAKIA
}

\author{
M. Goga and M. Dudášs \\ Institute of Biology \& Ecology, Faculty of Science, P. J. Šafárik University, Mánesova 23, \\ SK-041 54, Košice, Slovakia; E-mails: michal.goga@upjs.sk, dudas.mato@gmail.com
}

(Received 22 January, 2018; Accepted 3 September, 2018)

\begin{abstract}
We present the results of lichenological survey in the area of Zemplínske vrchy Mts in this paper. The study area is underexplored regarding lichens and there are not many published resources on lichens. In total thirty-five localities were investigated and 68 lichen species were identified. Fifteen species of them are evaluated in the Red list of lichens of Slovakia. From interesting findings, Cladonia crispata, Graphis scripta, Lecanora conizaeoides and Flavoparmelia caperata are discussed here. Physcia leptalea is reported for the first time for the area of Slovakia.
\end{abstract}

Key words: central Europe, lichen diversity, lichenized fungi, Western Carpathians

\section{INTRODUCTION}

Zemplínske vrchy Mts (Western Carpathians, SE Slovakia) are small volcanic mountains with an area of $103 \mathrm{~km}^{2}$ located in southeastern Slovakia as a western part of the Eastern Slovakian Lowland (Fig. 1). It represents one of the oldest volcanic mountains, composed of Palaeozoic-Mesozoic and partly neovolcanic rocks. The highest elevation point is Rozhl'adňa hill (470 $\mathrm{m}$ a.s.l.). Forests cover approximately $39 \%$ of the territory. The oak-hornbeam forests with xeric and thermophilic species are the most predominant, however the beech and black locust forests represented in minority are also present. The secondary xerothermous pastures, grassland vegetation and the small quarries were formed by human activities on the periphery of the mountains (Fusán 1972, Futák 1972, Mártonfi 2014, Mráz et al. 2016). On the southern and southwestern slopes vineyards are located, which have been known as "Tokajská vinohradnícka oblast" ("Slovakian or smaller Tokaj wine region").

From geomorphological division of Slovakia, it belongs to the Inner Western Carpathians (Mazúr and Lukniš 1986), from phytogeographical point of view to the area of Pannonian flora region (Pannonicum) and phytogeographical district Eastern Slovakian Lowland (Futák 1984).

Calcareous area covers only $6.6 \%$ of the territory (Mráz et al. 2016), mainly near Ladmovce village. The most precious parts, Kašvár Nature Reserve and European protected area Ladmovské vápence (SKUEV0032) were estab- 
lished to protect the limestone karst elements with thermophilic and calcicolous vegetation. Southern parts of the mountains are bordered by the Latorica Protected Landscape Area (CHKO Latorica).

The aims of the study are to fill the lack information about lichen diversity knowledge in the study area and to present a list of recent lichen flora collected from the Zemplínske vrchy Mts. This paper contributes to the knowledge of lichens of southeastern Slovakia.

\section{MATERIALS AND METHODS}

The field work was carried out from November 2014 to March 2015 in a period without snow cover in the Zemplínske vrchy Mts. Samples were collected for identification and are deposited in the private herbarium of the first author. Localities are shown in Figure 1. The investigated sites were georeferenced from Garmin eTrex 20 in the WGS-84 coordinate system.

The location map was processed using the ArcMap software (Department of Geography, Pavol J. Šafárik University, Košice), which shows collected coordinates from GPS receivers as point objects. The nomenclature of lichens follows Guttová et al. (2013a), the categories of threat are listed according to the Red list of lichens of Slovakia (Pišút et al. 2001). The nomenclature of vascular plants follows Marhold et al. (2007). Studies of herbarium collections were not included in this study. The specimen of Physcia leptalea is deposited in the private herbarium of the first author. All specimens were collected by the second author.

\section{List of the studied sites}

Information on localities is arranged as follows: the name of the closest village, locality, characterisation of the site, GPS coordinates, date of collection.

1. Cejkov, Vlčia hora hill ( $257 \mathrm{~m})$, meadow at the top, $48^{\circ} 28^{\prime} 24.0^{\prime \prime} \mathrm{N}, 21^{\circ}$ 45' 21.6" E, 16.11.2014.

2. Cejkov, windbreak between fields, $48^{\circ} 28^{\prime} 45.5^{\prime \prime} \mathrm{N}, 21^{\circ} 45^{\prime} 15.8^{\prime \prime} \mathrm{E}$, 16.11.2014.

3. Cejkov, Vlčia hora hill, old abandoned vineyard, $48^{\circ} 28^{\prime} 31^{\prime \prime} \mathrm{N}, 21^{\circ} 45^{\prime}$ 24" E, 16.11.2014.

4. Cejkov, roadsides cross monument (God's torture) towards to Kašov village, $48^{\circ} 28^{\prime} 28.89^{\prime \prime} \mathrm{N}, 21^{\circ} 44^{\prime} 53.02^{\prime \prime} \mathrm{E}, 16.11 .2014$.

5. Cejkov, Castle hill (= Várhegy, hill 213), quarry, pine-birch forest, $48^{\circ}$ $28^{\prime} 2.01^{\prime \prime} \mathrm{N}, 21^{\circ} 46^{\prime} 1.59^{\prime \prime} \mathrm{E}, 23.11 .2014$. 


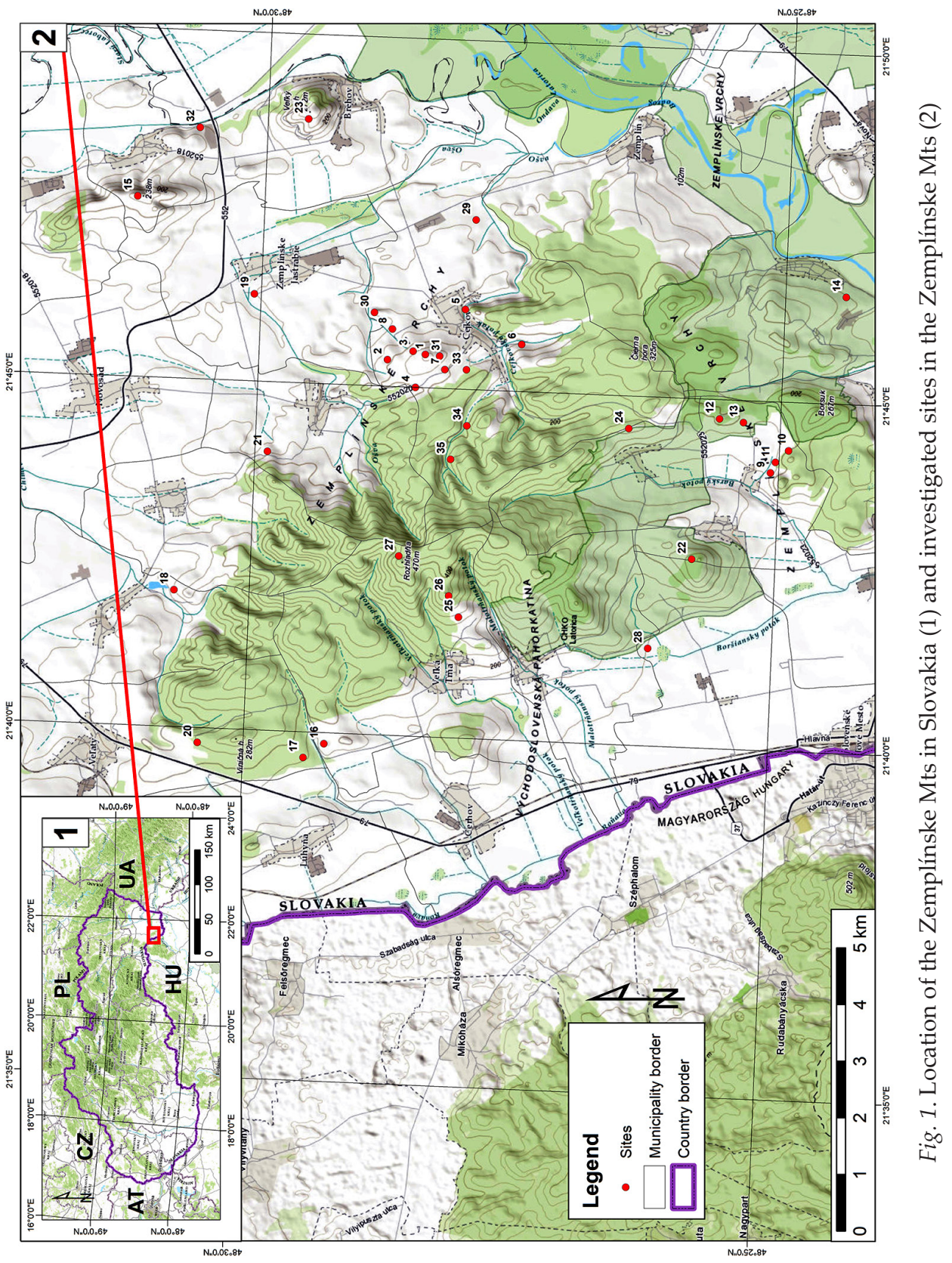


6. Cejkov, old abandoned pastures near game reserve, in terrain depression and on field roadside, $48^{\circ} 27^{\prime} 29.11^{\prime \prime} \mathrm{N}, 21^{\circ} 45^{\prime} 33.47^{\prime \prime} \mathrm{E}, 30.11 .2014$.

7. Cejkov, roadside scrubs towards to Kašov village, $48^{\circ} 28^{\prime} 12.47^{\prime \prime} \mathrm{N}, 21^{\circ}$ $45^{\prime}$ 9.29" E, 29.11.2014.

8. Cejkov, Tokajík hill (= Tokajský hill, $159 \mathrm{~m}$ ), abandoned quarry, $48^{\circ} 28^{\prime}$ 43.38" N, 21 45' 42.31" E, 29.11.2014.

9. Malá Bara, Stredný vrch hill, solitary volcanic rocks on former pasture, $48^{\circ} 25^{\prime} 3.90^{\prime \prime} \mathrm{N}, 21^{\circ} 43^{\prime} 51.81^{\prime \prime} \mathrm{E}, 23.11 .2014$.

10. Malá Bara, Stredný vrch hill, abandoned quarry, $48^{\circ} 24^{\prime} 54.02^{\prime \prime} \mathrm{N}, 21^{\circ}$ $44^{\prime}$ 11.44" E, 23.11.2014.

11. Malá Bara, Stredný vrch hill, xerothermous oak grove, $48^{\circ} 25^{\prime} 1.28^{\prime \prime}$ $\mathrm{N}, 21^{\circ} 44^{\prime} 1.04^{\prime \prime} \mathrm{E}, 23.11 .2014$.

12. Malá Bara, Brezinka hill, southern slopes, beech forest, $48^{\circ} 25^{\prime} 34.25^{\prime \prime}$ $\mathrm{N}, 21^{\circ} 44^{\prime} 36.5^{\prime \prime} \mathrm{E}, 6.12 .2014$.

13. Malá Bara, site Bečked, old quarry, $48^{\circ} 25^{\prime} 20.52^{\prime \prime} \mathrm{N}, 21^{\circ} 44^{\prime} 34.13^{\prime \prime}$ E, 7.12.2014.

14. Ladmovce, Šomoš hill, Kašvár Nature Reserve, karst depressions, $48^{\circ}$ $24^{\prime} 53^{\prime \prime} \mathrm{N}, 21^{\circ} 46^{\prime} 25^{\prime \prime} \mathrm{E}, 20.12 .2014$.

15. Sirník, hill 236, around transmitter on the top, on rocks and branches of Crataegus sp. and Prunus spinosa, 48 31' 11.96" N, 21 ${ }^{\circ} 47^{\prime} 28.12^{\prime \prime}$ E, 7.12.2014.

16. Vel'ká Tŕňa, old quarry, $48^{\circ} 29^{\prime} 13^{\prime \prime} \mathrm{N}, 21^{\circ} 39^{\prime} 43.6^{\prime \prime} \mathrm{E}, 6.12 .2014$.

17. Vel'ká Tŕńa, old quarry, $48^{\circ} 29^{\prime} 24.5^{\prime \prime} \mathrm{N}, 21^{\circ} 39^{\prime} 31^{\prime \prime} \mathrm{E}, 6.12 .2014$.

18. Hrčel', Baňa hill and quarry, $48^{\circ} 30^{\prime} 42.3^{\prime \prime} \mathrm{N}, 21^{\circ} 41^{\prime} 50.8^{\prime \prime} \mathrm{E}, 13.12 .2014$

19. Zemplínske Jastrabie, hill 127 , sand quarry, $48^{\circ} 30^{\prime} 3.11^{\prime \prime} \mathrm{N}, 21^{\circ} 46^{\prime}$ 7.8” E, 13.12.2014.

20. Velaty, car camping ATC Mária, margin of oak forest near parking, $48^{\circ} 30^{\prime} 25.32^{\prime \prime} \mathrm{N}, 21^{\circ} 39^{\prime} 40.22^{\prime \prime} \mathrm{E}, 12.12 .2014$.

21. Kašov, Strekov site, scrub on meadow, $48^{\circ} 29^{\prime} 52^{\prime \prime}$ N, $21^{\circ} 43^{\prime} 53^{\prime \prime}$ E, 21.12.2014.

22. Vel'ká Bara, Piliš hill $(278 \mathrm{~m})$, scrubs on field roadside to the top, $48^{\circ}$ $25^{\prime} 47^{\prime \prime} \mathrm{N}, 21^{\circ} 42^{\prime} 35^{\prime \prime}$ E, 20.12.2014.

23. Brehov, Vel'ký vrch hill (272 m), quarry, $48^{\circ} 29^{\prime} 36^{\prime \prime} \mathrm{N}, 21^{\circ} 48^{\prime} 40^{\prime \prime} \mathrm{E}$, 21.12.2014.

24. Černochov, scrubs on meadow, $48^{\circ} 26^{\prime} 26^{\prime \prime} \mathrm{N}, 21^{\circ} 44^{\prime} 25^{\prime \prime} \mathrm{E}, 20.12 .2014$.

25. Vel'ká Tŕňa, scrubs on forest edge, $48^{\circ} 27^{\prime} 59^{\prime \prime} \mathrm{N}, 21^{\circ} 41^{\prime} 37^{\prime \prime} \mathrm{E}$, 30.12.2014.

26. Vel'ká Tŕňa, oak grove, $48^{\circ} 28^{\prime} 05^{\prime \prime} \mathrm{N}, 21^{\circ} 41^{\prime} 55^{\prime \prime}$ E, 30.12.2014.

27. Vel'ká Tŕňa, Rozhl'adňa hill $(470 \mathrm{~m})$, on decayed oak stump, $48^{\circ} 28^{\prime}$ 34.5” N, 21 42' 27.6" E, 30.12.2014.

28. Bara, settlement Káty, scrubs on roadside, $48^{\circ} 26^{\prime} 10^{\prime \prime} \mathrm{N}, 21^{\circ} 41^{\prime} 17^{\prime \prime}$ E, 30.12.2014. 
29. Cejkov, site Piesky, sand quarry, $48^{\circ} 27^{\prime} 58^{\prime \prime} \mathrm{N}, 21^{\circ} 47^{\prime} 19^{\prime \prime} \mathrm{E}, 29.12 .2014$.

30. Cejkov, Tokajík hill (159 m), scrubs on archaeological site, $48^{\circ} 28^{\prime} 54^{\prime \prime}$ $\mathrm{N}, 21^{\circ} 45^{\prime} 56^{\prime \prime} \mathrm{E}, 21.12 .2014$.

31. Cejkov, Vlčia hora hill $(257 \mathrm{~m})$, scrubs on field roadside to the top, $48^{\circ}$ $28^{\prime} 15.7^{\prime \prime} \mathrm{N}, 21^{\circ} 45^{\prime} 20.6^{\prime \prime} \mathrm{E}, 10.1 .2015$.

32. Sirník, abandoned quarry near former collective farm, $48^{\circ} 30^{\prime} 37.8^{\prime \prime} \mathrm{N}$, $21^{\circ} 48^{\prime}$ 29.1" E, 31.1.2015.

33. Cejkov, Potočková forest, $48^{\circ} 28^{\prime} 00.1^{\prime \prime} \mathrm{N}, 21^{\circ} 45^{\prime}$ 09.9” E, 1.2.2015.

34. Cejkov, Bocianí vrch hill (267 m), northern slope (local name Tistaš), $48^{\circ} 27^{\prime} 58.6^{\prime \prime} \mathrm{N}, 21^{\circ} 44^{\prime} 21.8^{\prime \prime} \mathrm{E}, 22.3 .2015$.

35. Cejkov, Plochá hora hill (348 m), northern slope (local name Wambengerov I), $48^{\circ} 28^{\prime} 07.1^{\prime \prime} \mathrm{N}, 21^{\circ} 43^{\prime} 52.4^{\prime \prime} \mathrm{E}, 22.3 .2015$.

\section{LIST OF THE RECORDED SPECIES}

Abbreviations of phorophytes: $\mathrm{Ac}=$ Acer campestre, $\mathrm{Bp}=$ Betula pendula, $\mathrm{Cb}=$ Carpinus betulus, $\mathrm{C}=$ Crataegus sp., $\mathrm{Pt}=$ Populus tremula, $\mathrm{Ps}=$ Prunus spinosa, $\mathrm{Psy}=$ Pinus sylvestris, $\mathrm{Pc}=$ Populus canadensis, $\mathrm{Qr}=$ Quercus robur, $\mathrm{Q}=$ Quercus sp., $\mathrm{Rc}=$ Rosa canina, $\mathrm{Sn}=$ Sambucus nigra, $\mathrm{Sc}=$ Salix caprea . Remark: the first report for the area of Slovakia is indicated by an asterisk $\left(^{*}\right)$.

Acarospora cf. nitrophila H. Magn. agg. - 15 (on Pt), 23 (on Pt, Ps), 29 (on Pt);

Amandinea punctata (Hoffm.) Coppins et Scheid. - 1-8, 11-13, 15, 18, 21, 23-26, 28, 30, 31, 33 (on different substrates);

Caloplaca saxicola (Hoffm.) Nordin - 18 (on ryodacite rocks);

Candelariella aurella (Hoffm.) Zahlbr. - 14 (on limestone rocks), 15 (on andesite rocks);

Candelariella sp. -35 (on $\mathrm{Cb}$ );

Chrysothrix candelaris (L.) J. R. Laundon - 22 (on Psy);

Circinaria contorta (Hoffm.) A. Nordin, S. Savić et Tibell - 14 (on limestone rocks);

Cladonia arbuscula (Wallr.) Flot. - 13 (on ground);

Cladonia cariosa (Ach.) Spreng. - 13 (on ground), 34 (on ground among mosses);

Cladonia coniocraea (Flörke) Spreng. - 20 (on Qr), 27 (on Q), 35 (on bark $\mathrm{Cb}$ at base);

Cladonia convoluta (Lam.) Anders - VU - 14 (on ground in grassy steppe);

Cladonia crispata (Ach.) Flot. - VU - 13 (on ground among mosses);

Cladonia fimbriata (L.) Fr. - 6, 12, 18, 23, 34 (at each sites on ground);

Cladonia foliacea (Huds.) Willd. - 12 (on red-grey sandstone);

Cladonia furcata (Huds.) Schrad. - 5, 10, 12-16, 23, 34 (at each sites on ground among mosses); 
Cladonia pocillum (Ach.) Grognot - 23 (on andesite rocks);

Cladonia polydactyla (Flörke) Spreng. - 12 (on red-grey sandstone), 17 (on volcanic rocks), 26 (on ground);

Cladonia pyxidata (L.) Hoffm. - 10 (on volcanic rocks), 12 (on red-grey sandstone), 14 (between limestone rocks);

Cladonia rangiformis Hoffm. - 5 (on ground), 12 (on ground);

Cladonia squamosa (Scop.) Hoffm. - 12 (on red-grey sandstone);

Cladonia subulata (L.) F. H. Wigg. - 23 (on andesite rocks);

Dibaeis baeomyces (L. f.) Rambold et Hertel -6 (on brown clay);

Evernia prunastri (L.) Ach. - EN - 2, 3, 6, 7, 11, 12, 14, 16, 18, 20-28, 30, 35 (mainly on Ps);

Flavoparmelia caperata (L.) Hale - EN - 5 (on Q), 7 (on Ac), 15 (on Ps), 26 (on $\mathrm{Q}$ ), 30 (on Ps), 32 (on C);

Graphis scripta (L.) Ach. - EN - 35 (on Cb);

Hypogymnia physodes (L.) Nyl. - 3, 5-7, 11, 12, 14, 16, 18, 22-28, 30, 35 (on different phorophytes);

Hypogymnia tubulosa (Schaer.) Hav. - LR:nt - 6 (on Ps, Ac), 22 (on Ps, Qr), 28 (on Ps);

Lecania cyrtella (Ach.) Th. Fr. - DD - 2 (on Ps), 3 (on Ps), 24 (on Ps), 29 (on $\mathrm{Pt}$ ), 31 (on Ps, Rc); 33 (on Pt);

Lecania naegelii (Hepp) Diederich et van den Boom - 29 (on Pt), 30 (on Ps),

Lecanora carpinea (L.) Vain. - 33 (on Cb), 35 (on Cb);

Lecanora chlarotera Nyl. - 20 (on Qr);

Lecanora conizaeoides Nyl. ex Cromb. - 20 (on Qr);

Lecanora crenulata Hook. - 18 (on ryodacite rocks);

Lecanora dispersa (Pers.) Sommerf. - 14 (on limestone rocks);

Lecanora saxicola (Pollich) Ach. - 14 (on limestone rocks), 15 (on andesite rocks), 32 (on andesite rocks);

Lecanora symmicta (Ach.) Ach. - 3 (on C, Ps), 6 (on Ps, Ac), 18 (on Ps), 28 (on Ps), 30 (on Ps, Rc);

Lecidella carpathica Körb. - 23 (on Pt);

Lecidella elaeochroma (Ach.) M. Choisy - 25 (on Ps), 35 (on Cb);

Lepraria sp. - 10 (on volcanic rocks), 17 (on Qr), 26 (on Q), 33 (on Qr);

Melanelixia glabratula (Lamy) Sandler et Arup (syn. Parmelia grabratula) 33 (on Qr), 35 (on Qr);

Melanelixia subaurifera (Nyl.) O. Blanco, A. Crespo, Divakar, Essl., D. Hawksw. et Lumbsch - 6 (on Ps), 12 (on Ps, Qr), 18 (on Ps), 21 (on Ps), 24 (on Ps), 25 (on Ps, Rc);

Melanohalea exasperatula (Nyl.) O. Blanco, A. Crespo, Divakar, Essl., D. Hawksw. et Lumbsch - 35 (on $\mathrm{Cb}$ ); 
Parmelia sulcata Taylor - 1, 3-7, 11-13, 15, 19, 21, 22, 24, 25, 28, 31, 33, 35 (on different phorophytes);

Peltigera horizontalis (Huds.) Baumg. - 14 (between limestone rocks in grassy steppe);

Peltigera rufescens (Weiss) Humb. - 35 (on Qr);

Pertusaria albescens (Huds.) M. Choisy et Werner - LR:nt - 20 (on Qr, Sn);

Phaeophyscia orbicularis (Neck.) Moberg - 1 (on Qr), 2 (on Pc), 7 (on Ac, Ps), 8 (on Sn), 19 (on Pt, Sc), 28-31 (on Ps, Rc, Pt);

Phlyctis argena (Spreng.) Flot. - 17 (on Qr);

Physcia adscendens H. Olivier - 1, 2, 4-8, 13, 17-25, 28, 29, 31, 33, 35 (mainly on Ps, Rc, Qr);

Physcia aipolia (Ehrh. ex Humb.) Fürnr. - 3 (on Ps), 5 (on Qr), 7 (on Ps), 12 (on Qr, Bp), 16 (on Pt), 21 (on Ps), 24 (on Ps), 31 (on Ps, C), 32 (on C);

*Physcia leptalea (Ach.) DC. - 31 (on Ps);

Physcia stellaris (L.) Nyl. - 1, 6, 8, 25, 29, 30, 33 (mainly on Qr, Pt);

Physcia tenella (Scop.) DC. - 15 (on Ps, C), 28 (on Ps);

Porina aenea (Wallr.) Zahlbr. - 35 (on $\mathrm{Cb}$ );

Porpidia crustulata (Ach.) Hertel et Knoph - 18 (on ryodacite rocks);

Pseudevernia furfuracea (L.) Zopf - LR:nt - 3, 5, 6, 11, 12, 16, 18, 20-25, 28, 31 (on different phorophytes);

Ramalina farinacea (L.) Ach. - EN - 7 (on Ps), 28 (on Ps);

Rinodina pyrina (Ach.) Arnold - VU - 24 (on Ps), 28 (on Ps);

Rinodina sophodes (Ach.) A. Massal. - VU - 3 (on Ps);

Sarcogyne regularis Körb. - 14 (on limestone rocks);

Scoliciosporum chlorococcum (Graewe ex Stenh.) Vězda - 6 (on Ps), 25 (on Q, Ps), 26 (on Q), 28 (on Ps), 31 (on Ps, Rc);

Usnea cf. hirta (L.) F. H. Wigg. - VU - 18, 24, 25, 28, 30 (all on Ps, Rc);

Verrucaria cf. rupestris Schrad. - 18 (on ryodacite rocks);

Xanthoparmelia conspersa (Ehrh. ex Ach.) Hale - 9 (on volcanic rocks);

Xanthoparmelia pulla (Ach.) O. Blanco, A. Crespo, Elix, D. Hawksw. et Lumbsch - 9 (on volcanic rocks);

Xanthoparmelia stenophylla (Ach.) Ahti et D. Hawksw. - 9 (on volcanic rocks);

Xanthoria parietina (L.) Th. Fr. - LR:nt - 1-4, 6-8, 12-15, 18-21, 23-25, 28-30, 32, 33 (on different substrates);

Xanthoria polycarpa (Hoffm.) Th. Fr. ex Rieber - LR:nt - 20 (on Qr).

\section{DISCUSSION}

The records of lichens from the Zemplínske vrchy Mts. are not well known and the investigation of this area was more than necessary, although 
the vascular plants in the territory were explored properly during the Floristical course (Mártonfi 2014). The area is underexplored regarding lichens and attractive habitats as limestones, volcanic rocks and sandstone soils exist here. The Hungarian adjacent Zempléni- and Tokaj-hegység mountains were explored during last centuries (e.g. Hazslinszky 1866, Verseghy 1964).

During our field research in the Zemplínske vrchy Mts 68 lichen species were collected from 35 localities. Fifteen species are included in four categories of threat level in the red list of lichens of Slovakia: 5 vulnerable (VU), 4 endangered (EN), 5 lower risk: near threatened (LR:nt) and 1 data deficient (DD).

The highest diversity was recorded in the genus Cladonia (14 species), Lecanora (7 species), Physcia (5 species) and Xanthoparmelia (3 species). From the total amount of 68 recorded species we noted 10 species were observed growing in more than 8 localities, 9 species in $4-8$ localities, 15 species in 2-3 localities and 35 species recorded only in a single locality.

The most frequent lichen species in the Zemplínske vrchy Mts growing in more than eight localities were Amandinea punctata, Cladonia furcata, Evernia prunastri, Hypogymnia physodes, Parmelia sulcata, Phaeophyscia orbiscularis, Physcia adscendens, Physcia aipolia, Pseudevernia furfuracea and Xanthoria parietina. These species grow quite commonly in a number of populations in suitable habitats in the whole study area.

Twenty-four species were recorded from 2 to 8 localities, but it is probability of founded new places of occurrence in study area. In case of Usnea cf. hirta, many juvenile lichen thalli are distributed in village of Cejkov in orchards, mainly on branches of old plum and apple trees, but these sites were not included in this study. Lichen thalli grow hidden between branches of trees and the thallus is never longer than $5 \mathrm{~cm}$, therefore it is easily overlooked.

The most important findings of species recorded from 34 one-locality are considered to be Physcia leptalea, Cladonia crispata, Graphis scripta, Flavoparmelia caperata and Lecanora conizaeoides.

Physcia leptalea: This is the first report within the country. The species has not been listed in the checklists of lichens of Slovakia so far (Guttová et al. 2013a, Pišút et al. 2001). P. leptalea can be found on evergreen or on deciduous trees, very often on trunk of trees in open situations. It is a close relative of $P$. adscendens and P. tenella but apothecia are abundant and the appearance is more robust. The thallus is irregular, up to $4 \mathrm{~cm}$ in diameter. The colour of the upper side is white-grey to grey, rarely dark grey. Lobes are long and narrow, up to $1 \mathrm{~mm}$ wide but sometimes can be shorter and $2 \mathrm{~mm}$ wide. Soralia are not present. The underside is pale grey to brown colour with a few rhizines. Apothecia are common up to $3 \mathrm{~mm}$ in diameter. The size of spores is $17-22 \times 7-10$ 
$\mu \mathrm{m}$ (Wirth et al. 2013). The new record was discovered on Vlčia hora hill near Cejkov village in dense growth of shrubs with Prunus spinosa as dominant.

Cladonia crispata: Within Slovakia, the species is abundant in the Tatra Mts (cf. Lisická 2005), only a single locality was found in Borská nížina lowland (Dingová and Pišút 2009), Levočské vrchy Mts. (Szatala 1930) and Štiavnické vrchy Mts. (Sántha 1916). Verseghy (1964) recorded it from the adjacent northeastern Hungary from the Zempléni-hegység Mts. No records are published from southeastern Slovakia. The newly discovered locality represents an old and abandoned small quarry near Malá Bara village. The small population growing here is endangered by an illegal waste dump. We expect to discover other populations in the nearest oak-birch forest on rocky clearings, where suitable habitats exist, but during field research we did not record it. The species is listed as vulnerable (VU) in the Red list of lichens of Slovakia (Pišút et al. 2001).

Graphis scripta: G. scripta occurs within the whole territory of Slovakia and it prefers beech, oak and hornbeam forests (Pišút 1999). A newly discovered location was recorded on bark of Carpinus betulus in Plochá hora hill in the central part of the Zemplínske vrchy Mts. The probability of new discoveries in this area is very high because the suitable habitats exist here. From adjacent Hungarian area, Farkas and Tuba (2005) reported this species from the northern parts of the Hungarian Great Plain. It is evaluated in category endangered (EN; Pišút et al. 2001).

Lecanora conizaeoides: L. conizaeoides grows on park trees in urban environments, and in other very acidic and polluted environments as well. $L$. conizaeoides is a common epiphytic lichen in industrial areas of western Europe (Stenroos et al. 2016) and was widespread in Slovakia in the past because of high $\mathrm{SO}_{2}$ levels (Guttová et al. 2013b). When the air quality has improved (decrease of $\mathrm{SO}_{2}$ ), the occurrence of this species declined or disappeared entirely (Stenroos et al. 2016). This species was recorded mainly in the western and the central parts of Slovakia (e.g. Guttová and Pišút 2007, Guttová et al. 2015, 2017, Lackovičová and Pišút 2004, Pišút 1985). The new locality in the Zemplínske vrchy Mts is located on the forest margin near a truck parking in Autocamping Mária resort.

Flavoparmelia caperata (syn. Parmelia caperata): The species is known in Slovakia from oak forests of the western and the central part of the country (e.g. Guttová and Pišút 2007, Lisická 2005). Six localities were discovered in the Zemplínske vrchy Mts, whereas the lichens grown on branches of deciduous shrubs (Prunus spinosa, Crataegus sp.) and trees (Quercus robur). From the adjacent Hungarian area, Verseghy (1964) reported the species from the Zempléni-hegység Mts and Farkas and Tuba (2005) reported only one historical occurrence from the Hungarian Bodrogköz. 
From the point of view of lichen diversity, two localities are considered as very important. The first and the most valuable is Kašvár Nature Reserve near Ladmovce village (site nr. 14) with karst elements and numerous of terrain depression on Šomoš hill with rich population of few Cladonia species $(C$. convoluta, C. furcata, and C. pyxidata) and calcicolous species (Circinaria contorta and Sarcogyne regularis). The second one is Brezinka hill near Malá Bara village (site nr. 12) composed of red-grey sandstone with rhyolite admixture. Approximately 0.2 ha large hillside is populated with low birch trees (Betula pendula), oaks (Quercus spp.) and aspen trees (Populus tremula) with poor herbaceous vegetation, but the coverage of lichens and mosses reaches the abundance of $90 \%$. The most interesting records are Cladonia foliacea, C. squamosa and $C$. rangiformis, whereas the last species is forming the bunch of thallus over $20 \mathrm{~cm}$ in diameter in area over $10 \mathrm{~m}^{2}$.

The lichen flora of the Zemplínske vrchy Mts has not been well studied so far. Our list of lichens brings the overview of 68 recent lichen species diversity in this area and can be extended in the future. The most important findings in the territory of southeastern Slovakia include the new record of Physcia leptalea for Slovakia and interesting records of lichens Cladonia crispata, Graphis scripta, Flavoparmelia caperata and Lecanora conizaeoides.

Acknowledgements - We thank to Jozef Šupinský (Košice, Slovakia) for creating the map. We also thank to Anna Guttová (Bratislava, Slovakia) for help with identification and valuable advices. We also thank Marianna Gazdiková and Dominika Vašková (Košice, Slovakia) for correction of the English language. The field research was supported by KEGA 012UPJŠ-4/2016.

\section{REFERENCES}

Dingová, A. and Pišút, I. (2009): Doplnky k poznaniu lišajníkov Borskej nížiny (Juhozápadné Slovensko). - Bryonora 44: 28-33.

Farkas, E. and Tuba, Z. (2005): Contributions to the lichen flora of the Hungarian Bodrogköz (NE Hungary). - Thaiszia, J. Bot. 15: 129-141.

Fusán, O. (1972): Geológia. - In: Lukniš, M. (ed.): Slovensko 2. Príroda. Obzor Bratislava, pp. 20-123.

Futák, J. (1972): Fytogeografický prehl'ad Slovenska. - In: Lukniš, M. (ed.): Slovensko 2. Príroda. Obzor Bratislava, pp. 431-482.

Futák, J. (1984): Fytogeografické členenie Slovenska. - In: Bertová, L. (ed.): Flóra Slovenska IV/1. Veda, Bratislava, pp. 418-419.

Guttová, A. and Pišút, I. (2007): Lišajníky Záhorskej nížiny (JZ Slovensko). - Bryonora 39: $1-12$.

Guttová, A., Lackovičová, A. and Fačkovcová, Z. (2015): Diverzita lišajníkov prírodnej rezervácie Klapy (CHKO Strážovské vrchy). - Bryonora 55: 37-45. 
Guttová, A., Lackovičová, A. and Pišút, I. (2013a): Revised and updated checklist of lichens of Slovakia (May 2013). - Biologia 68(5): 845-850. https://doi.org/10.2478/s11756-013 $-0218-y$

Guttová, A., Petríková, K. and Senko, D. (2013b): Epiphytic lichen flora of urban areas as an indicator of air quality in Spišská Nová Ves (eastern Slovakia). - Bull. Slov. Bot. Spoločn., Bratislava 35(1): 11-24.

Guttová, A., Fačkovcová, Z., Munzi, S., Lackovičová, A., Pišút, I. and Košuthová, A. (2017): Lecanora conizaeoides (report). In: Eliáš, P. jun. (ed.): Zaujímavejšie floristické nálezy. - Bull. Slov. Bot. Spoločn., Bratislava 39(2): 210.

Hazslinszky, F. (1866): A Tokaj-hegyalja viránya. - Math. Term.tud. Közlem. 4: 105-143.

Lackovičová, A. and Pišút, I. (2004): Lišajníky národnej prírodnej rezervácie Dobročský prales (Klenovský Vepor, Veporské vrchy). - Bull. Slov. Bot. Spoločn., Bratislava, 26: 23-30.

Lisická, E. (2005): The lichens of the Tatry Mountains. - Veda, Bratislava, 439 pp.

Marhold, K., Mártonfi, P., Mered’a, P. jun., Mráz, P., Hodálová, I., Kolník, M., Kučera, J., Lihová, J., Mrázová, V., Perný, M. and Valko, I. (2007): Karyological database of the ferns and flowering plants of Slovakia. (Karyologická databáza paprad'orastov a semenných rastlín Slovenska). Version 1.0. - http://www.chromosomes.sav.sk, cit. 20. 10. 2017.

Mártonfi, P. (ed.) (2014): Flóra okolia Trebišova. - Bull. Slov. Bot. Spoločn., Bratislava, 36(Suppl. 1): 1-80.

Mazúr, E. and Lukniš, M. (1986): Geomorfologické členenie SSR a ČSSR. - Slovenská Kartografia, Bratislava.

Mráz, P., Barabas, D., Lengyelová, L., Turis, P., Schmotzer, A., Janišová, M. and Ronikier, M. (2016): Vascular plant endemism in the Western Carpathians: spatial patterns, environmental correlates and taxon traits. - Biol. J. Linn. Soc. 119(2): 630-648. https:// doi.org/10.1111/bij.12792

Pišút, I. (1985): Die aktuelle Verbreitung einiger epiphytischen Flechtenarten in der Slowakei I. - Zbor. Slov. Nár. Múz., Prír. Vedy 31: 3-26.

Pišút, I. (1999): Mapovanie rozširenia epifytických lišajníkov na Slovensku (1970-1981). - Botanický ústav SAV, Bratislava.

Pišút, I., Guttová, A., Lackovičová, A. and Lisická, E. (2001): Červený zoznam lišajníkov Slovenska (december 2001). - In: Baláž, D., Marhold, K. and Urban, P. (eds): Červený zoznam rastlín a živočíchov Slovenska. Ochrana Prírody 20 (Supplement), Bratislava, pp. 23-32.

Sántha, L. (1916): Fucskó Mihály zuzmógyűjtése Selmecbánya környéken. - Bot. Közlem. 15: $168-175$.

Stenroos, S., Velmala, S., Pykälä, J. and Ahti, T. (eds) (2016): Lichens of Finland. - Norrlinia 30: $1-896$.

Szatala, Ö. (1930): Lichenes Hungariae. II. Gymnocarpeae (Graphidineae, Cyclocarpineae: Lecanactidaceae-Peltigeraceae). - Folia Cryptog. 1: 833-928.

Verseghy, K. (1964): Angaben zur Flechtenflora des Zemplén-Gebirges I. Strauch- und Laubflechten. - Fragm. Bot. Mus. hist.-nat. Hung. 3(1-4): 41-75.

Wirth, V., Hauck, M. and Schultz, M. (2013): Die Flechten Deutschlands. - Ulmer, Stuttgart, $1244 \mathrm{pp}$. 
